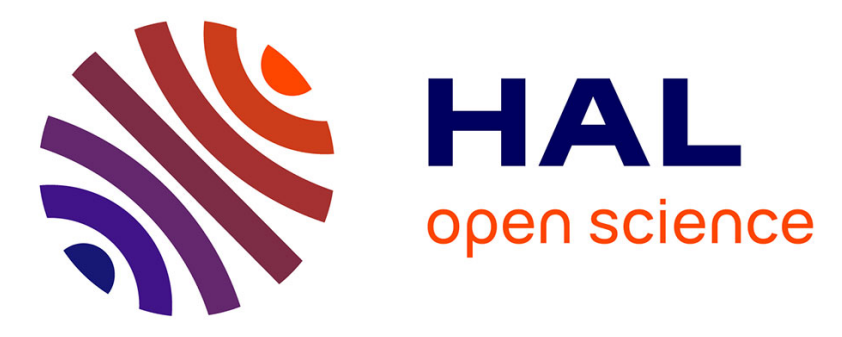

\title{
Alternative aluminum-based cocatalysts for the iron-catalyzed oligomerization of ethylene.
}

Adrien Boudier, Pierre-Alain Breuil, Lionel Magna, Hélène Olivier-Bourbigou, Pierre Braunstein

\section{- To cite this version:}

Adrien Boudier, Pierre-Alain Breuil, Lionel Magna, Hélène Olivier-Bourbigou, Pierre Braunstein. Alternative aluminum-based cocatalysts for the iron-catalyzed oligomerization of ethylene.. Dalton Transactions, 2015, 44 (29), pp.12995-12998. 10.1039/c5dt01367d . hal-01207898

\section{HAL Id: hal-01207898 \\ https://hal.science/hal-01207898}

Submitted on 1 Oct 2015

HAL is a multi-disciplinary open access archive for the deposit and dissemination of scientific research documents, whether they are published or not. The documents may come from teaching and research institutions in France or abroad, or from public or private research centers.
L'archive ouverte pluridisciplinaire HAL, est destinée au dépôt et à la diffusion de documents scientifiques de niveau recherche, publiés ou non, émanant des établissements d'enseignement et de recherche français ou étrangers, des laboratoires publics ou privés. 
Alternative Aluminum-Based Cocatalysts for the Iron-Catalyzed Oligomerization of Ethylene

Adrien Boudier, ${ }^{\mathrm{a}}$ Pierre-Alain R. Breuil, ${ }^{\mathrm{a},{ }^{*}}$ Lionel Magna, ${ }^{\mathrm{a}}$ Hélène Olivier-Bourbigou $^{\mathrm{a}}$ and Pierre Braunstein ${ }^{\mathrm{b}}$

Multinuclear aluminum cocatalysts have been obtained by the reaction of various phenols, alcohols or diols with trimethylaluminum and were used in situ or as isolated, well-defined species, for the activation of an iron(II) or an iron(III) pre-catalyst for the oligomerization of ethylene. The best cocatalyst candidate involves 2,2'-biphenol (10) in a 10/AlMe 3 ratio of $2 / 3$.

Organoaluminum compounds play a key role as cocatalysts in ethylene oligomerization and polymerization. For iron-catalyzed ethylene transformations, methylaluminoxanes ${ }^{1}$ (MAOs) lead to the most active systems. ${ }^{2}$ However, these ill-defined cocatalysts evolve over time and extended storage is limited. Efforts are thus devoted to replace them. In the specific area of iron-catalyzed ethylene polymerization, trialkylaluminum compounds associated to alkylabstracting reagents and weakly coordinating anions, most notably boron-based compounds, have long been known as suitable activators. ${ }^{3}$ Tetraalkylaluminoxanes $\mathrm{R}_{2} \mathrm{AlOAlR}_{2}$, formed by partial hydrolysis of $\mathrm{AlEt}_{3}$ or $\mathrm{Al} i \mathrm{Bu}_{3}$, were also reported by Wang et al. ${ }^{4}$ Interestingly, non-hydrolytic synthetic routes can generate MAO-like cocatalysts from $\mathrm{AlMe}_{3}$ and benzophenone or carboxylic acids, which are active in iron-catalyzed ethylene polymerization. ${ }^{5}$ Partially hydrolyzed trimethylaluminum supported on silica has been described by Alt and coworkers $^{6}$ for iron-bis(imino)pyridine complex heterogenization, $\mathrm{Al} / \mathrm{Fe}$ ratio was lowered to 8 while maintaining the catalyst active for ethylene polymerization.

However, in the area of iron-catalyzed ethylene oligomerization, the main issue for cocatalysts is not about the product properties but rather the ability to readily activate and trigger the oligomerization process. Focusing on this transformation, examples of alternative cocatalysts to MAO or MMAO are scarce. Hanton et al. successfully replaced MMAO with $\mathrm{AlEt}_{3}$ in combination with the perfluoro-borate or -aluminates $\left[\mathrm{Ph}_{3} \mathrm{C}\right]\left[\left(\mathrm{B}\left(\mathrm{Ph}^{\mathrm{F}}\right)\right)_{4}\right]$ or $\left[\mathrm{Ph}_{3} \mathrm{C}\right]\left[\mathrm{Al}\left(\mathrm{O} t \mathrm{Bu}^{\mathrm{F}}\right)_{4}\right]$, respectively, to activate the bis(imino)pyridine complex A (Figure 1), although the catalytic system appeared to be temperaturesensitive and noticeable catalyst deactivation occurred. More recently, Sun et al. ${ }^{8}$ used diethylaluminum chloride as cocatalyst of a benzimidazole(imino)pyridine ferric iron precursor, albeit this system exhibited very low reactivity. In our hands, none of the commercial alkylaluminum compounds $\mathrm{AlMe}_{3}, \mathrm{AlEt}_{3}, \mathrm{Al}_{i} \mathrm{Bu}_{3}$, $\mathrm{AlCl}_{2} \mathrm{Et}$ or $\mathrm{AlClEt}_{2}$ proved to be suitable iron cocatalysts under our oligomerization catalytic conditions (complex A, $10 \mu \mathrm{mol}(\mathrm{Fe}), 500$ eq. Al, $50^{\circ} \mathrm{C}, 30$ bar ethylene).

Herein, we report unprecedented aluminum cocatalysts for the iron-catalyzed oligomerization of ethylene. They are formed by reaction of phenols, alcohols or diols with trimethylaluminum and may be used in situ or as isolated and easier to handle and keep, well-defined species. ${ }^{9}$

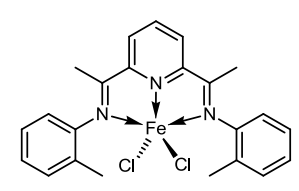

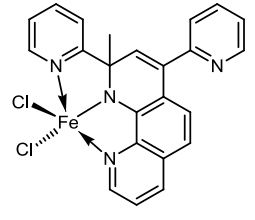

Fig 1 Iron(II) and iron(III) complexes used as precatalysts

We observed that the well-known complex $\mathbf{A}$ is activated by a solution of phenol $\mathbf{1}$ as additive and $\mathrm{AlMe}_{3}$ (molar $\mathrm{PhOH} / \mathrm{Al}=1 / 1$, prepared prior to use, see SI) under 30 bar of ethylene pressure and produces linear alpha olefins (up to $9.3 \times 10^{5} \mathrm{~g} \bullet(\mathrm{mol}(\mathrm{Fe}) \bullet \mathrm{h})^{-1}$, Figure 2 and Table 1 ). A plot of cumulative ethylene uptake over $1 \mathrm{~h}$ reveals slight catalyst deactivation (see ESI). A Schulz-Flory distribution of oligomers with $K=0.70$ was obtained, with no solid polymer (Table 1 , entry 1). Different phenols (2-3) and alcohols (4-5) were then evaluated in combination with $\mathrm{AlMe}_{3}$, for the activation of the iron complex but resulted in either lower activity in oligomerization of ethylene for 2,6-di-tert-butylphenol, 4-phenylphenol or cyclohexanol compared to phenol (up to $6.7 \times 10^{5} \mathrm{~g} \bullet(\mathrm{mol}(\mathrm{Fe}) \bullet \mathrm{h})^{-1}$, Table 1 , entries $\left.2-4\right)$, or, surprisingly, no activity as with tert-butanol (Table 1, entry 5). Little influence of the different cocatalysts was observed on the distribution of oligomers with $K=0.67$ 0.69 .

We also considered the use of diols in a molar ratio diol/AlMe $\mathrm{Al}_{3}=1 / 2$. Under our catalytic conditions, activation of complex $\mathbf{A}$ with $\mathrm{AlMe}_{3}$ and 1,2-ethanediol $\mathbf{6}$ afforded a rapidly deactivating system while with the longer 1,4-butanediol 7, a stable and active catalytic system was obtained (activities of $2.9 \times 10^{5} \mathrm{~g} \bullet(\mathrm{mol}(\mathrm{Fe}) \bullet \mathrm{h})$ ${ }^{1}$ and $12.9 \times 10^{5} \mathrm{~g} \bullet(\mathrm{mol}(\mathrm{Fe}) \cdot \mathrm{h})^{-1}$, respectively, Table 1 , entries 6 and 7). In comparison, tertiary and benzyl diols such as 1,1,2,2-tetraphenyl-1,2-ethanediol 8 and 2,2'biphenyldimethanol 9 led to inefficient cocatalysts (Table 1, entries 8 and 9). More interestingly, 2,2'-biphenol 10 or pyrocatechol 11 associated with $\mathrm{AlMe}_{3}$ afforded the most effective cocatalytic systems for the iron(II)catalyzed ethylene oligomerization (up to $55.9 \times 10^{5}$ $\mathrm{g} \bullet(\mathrm{mol}(\mathrm{Fe}) \bullet \mathrm{h})^{-1} \quad$ and $22.7 \times 10^{5} \quad \mathrm{~g} \bullet(\mathrm{mol}(\mathrm{Fe}) \bullet \mathrm{h})^{-1}$, respectively, Table 1 , entries 10 and 11). A controlled exotherm was observed $\left(<15^{\circ} \mathrm{C}\right)$ and linear alpha olefins were formed, with selectivities around $K=0.69-0.70$, along with waxes. Under the same operating conditions, complex $\mathbf{A}$ and MAO as cocatalyst led to extremely fast ethylene consumption. The non-controllable exothermicity of the reaction under these conditions led to more than $60 \mathrm{wt} \%$ of polymer and a Schulz-Flory distribution of oligomers ( $K=0.69$, Table 1 , entry 16$)$.

The two other isomeric dihydroxybenzene compounds 12 and $\mathbf{1 3}$ in combination with $\mathrm{AlMe}_{3}$ presented no activation ability (Table 1, entries 12 and 13), suggesting that the position of the hydroxyl groups should favor 
chelating geometries. Replacing one (14) or both (15) hydroxyl by amino groups led also to catalyst activation with slightly lower activities but good stability over $1 \mathrm{~h}$ (Table 1, entries 14 and 15).
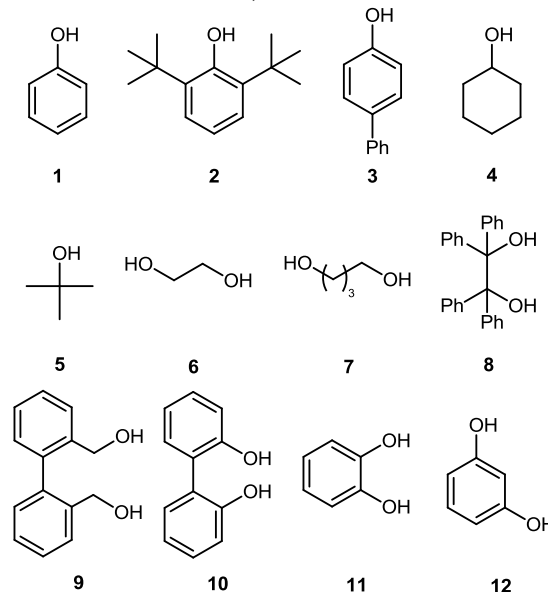

8<smiles>Oc1ccc(O)cc1</smiles><smiles>CCC</smiles>
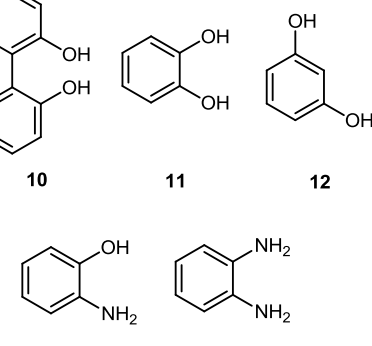

13

15

Fig 2 Phenols, alcohols and diols used as additives (addit.)

Table 1. Oligomerization of ethylene catalysed by complex $\mathbf{A}$ in combination with $\mathrm{AlMe}_{3}$ and different alcohols, phenols and diols as additives (addit.) ${ }^{a}$

\begin{tabular}{|c|c|c|c|c|}
\hline entry & $\begin{array}{c}\text { addit. } \\
\text { (addit./AlMe } \\
\text { ratio) }\end{array}$ & $\frac{\mathrm{m}_{\mathrm{C} 2 \mathrm{H} 4}}{(\mathrm{~g})^{b}}$ & activity $^{c}$ & $\mathrm{~K}^{\mathrm{d}}$ \\
\hline 1 & $1(1 / 1)$ & 9.3 & 9.3 & 0.70 \\
\hline 2 & $2(1 / 1)$ & 3.6 & 3.6 & 0.67 \\
\hline 3 & $3(1 / 1)$ & 4.6 & 4.6 & 0.67 \\
\hline 4 & $4(1 / 1)$ & 6.7 & 6.7 & 0.69 \\
\hline 5 & $5(1 / 1)$ & $<1$ & $0^{d}$ & - \\
\hline 6 & $6(1 / 2)$ & 2.9 & 2.9 & 0.66 \\
\hline 7 & $7(1 / 2)$ & 12.9 & 12.9 & 0.69 \\
\hline 8 & $8(1 / 2)$ & $<1$ & $0^{e}$ & - \\
\hline 9 & $9(1 / 2)$ & $<1$ & $0^{e}$ & - \\
\hline $10^{f}$ & $10(1 / 2)$ & 23.3 & 55.9 & 0.70 \\
\hline 11 & $11(1 / 2)$ & 22.7 & 22.7 & 0.69 \\
\hline 12 & $12(1 / 2)$ & $<1$ & $0^{d}$ & - \\
\hline 13 & $13(1 / 2)$ & $<1$ & $0^{d}$ & - \\
\hline 14 & $14(1 / 2)$ & 11.0 & 11.0 & 0.70 \\
\hline 15 & $15(1 / 2)$ & 11.6 & 11.6 & 0.67 \\
\hline $16^{g}$ & MAO & 62.0 & 740 & 0.69 \\
\hline
\end{tabular}

${ }^{a}$ Complex A (10 $\left.\mu \mathrm{mol}\right), \mathrm{AlMe}_{3}(500$ eq. $)$, toluene $(25 \mathrm{~mL})$, $P_{\mathrm{C} 2 \mathrm{H} 4}=30$ bar, $T=50{ }^{\circ} \mathrm{C}$, reaction time $1 \mathrm{~h} .{ }^{b}$ mass of ethylene introduced. ${ }^{c} \times 10^{5} \mathrm{~g} \bullet(\mathrm{mol}(\mathrm{Fe}) \cdot \mathrm{h})^{-1} \cdot{ }^{d} K=$ SchulzFlory coefficient $=\mathrm{k}_{\text {prop }} /\left(\mathrm{k}_{\text {prop }}+\mathrm{k}_{\mathrm{ch} \text { transfer }}\right)=\operatorname{mol}$ of $\mathrm{C}_{\mathrm{n}+2}$ oligomers / mol of $\mathrm{C}_{\mathrm{n}}$ oligomers. ${ }^{e}$ No ethylene uptake considered $(<1 \mathrm{~g}) .{ }^{f}$ Reaction time: $25 \mathrm{~min} .{ }^{g}$ Reaction time: 5 $\min , \mathrm{Al} / \mathrm{Fe}=500$.

Considering the reaction of the diols with $\mathrm{AlMe}_{3}$, different multinuclear aluminum species could be obtained depending on the stoichiometry of the reactants. ${ }^{10}$ We therefore tested different $10 / \mathrm{AlMe}_{3}$ molar ratios (Table 2) at constant $\mathrm{Al} / \mathrm{Fe}$ molar ratio (500) and

observed a maximum of activity for the 2/3 10/AlMe 3 molar ratio (up to $125.5 \times 10^{5} \mathrm{~g} \bullet(\mathrm{mol}(\mathrm{Fe}) \cdot \mathrm{h})^{-1}$, Table 2, entries 1-6) along with a non negligible exotherm (+40 ${ }^{\circ} \mathrm{C}$, see ESI). Increasing the molar ratio $10 / \mathrm{AlMe}_{3}$ and thus the relative number of hydroxyl groups led to a sharp decrease of the activation ability of the cocatalytic mixture (Table 2, entry 4), until no activity was detected for $10 / \mathrm{AlMe}_{3}=1 / 1$ or more (Table 2, entries 5-6). At the optimum 10/AlMe 3 molar ratio of $2 / 3$, the $\mathrm{Al} / \mathrm{Fe}$ ratio could be lowered to 250 without significant alteration of the catalyst activity $\left(100 \times 10^{5} \mathrm{~g} \bullet(\operatorname{mol}(\mathrm{Fe}) \bullet \mathrm{h})^{-1}\right.$, Table 2 , entry 7$)$. At a $\mathrm{Al} / \mathrm{Fe}$ ratio of 100 , a lower catalyst activity was observed $\left(83.7 \times 10^{5} \mathrm{~g} \bullet(\operatorname{mol}(\mathrm{Fe}) \bullet \mathrm{h})^{-1}\right.$, Table 2, entry $8)$, but the reaction temperature was perfectly controlled and the ethylene consumption was stable. Lowering the $\mathrm{Al} / \mathrm{Fe}$ ratio to 50 led to a decrease of activity and progressive deactivation of the catalytic system $\left(9.6 \times 10^{5}\right.$ $\mathrm{g} \bullet(\mathrm{mol}(\mathrm{Fe}) \bullet \mathrm{h})^{-1}$, Table 2 , entry 9$)$. Associated to complex $\mathrm{A}$, pyrocatechol 11 used in a ratio $11 / \mathrm{AlMe}_{3}=2 / 3$ led to a lower activity compared to the ratio $1 / 2\left(10.2 \times 10^{5}\right.$ $\mathrm{g} \cdot(\mathrm{mol}(\mathrm{Fe}) \cdot \mathrm{h})^{-1}$ vs $22.7 \times 10^{5} \mathrm{~g} \cdot(\mathrm{mol}(\mathrm{Fe}) \cdot \mathrm{h})^{-1}$, Table 2, entry 10 and Table 1 , entry 11 , respectively).

We then checked that this combination 10/AlMe $\mathrm{Al}_{3}(2 / 3)$ is not specific to the iron complex A by testing the iron(III) complex $\mathbf{B}$ (Figure 1). ${ }^{11} \mathrm{We}$ activated the latter using a $\mathrm{Al} / \mathrm{Fe}$ molar ratio of 250 at $80{ }^{\circ} \mathrm{C}$ and observed a short

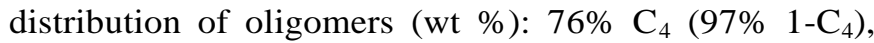
$13 \% \mathrm{C}_{6}\left(90 \% 1-\mathrm{C}_{6}\right), 13 \% \mathrm{C}_{8+}$ and $2 \%$ of polyethylene with an activity comparable to the one obtained with MAO at 200 eq. $\left(2.6 \times 10^{5} \mathrm{~g} \bullet(\mathrm{mol}(\mathrm{Fe}) \cdot \mathrm{h})^{-1}\right.$ vs $2.2 \times 10^{5}$ $\mathrm{g} \bullet(\operatorname{mol}(\mathrm{Fe}) \cdot \mathrm{h})^{-1}$, Table 2 , entries 11 and 12$)$.

Table 2. Iron-catalyzed oligomerization of ethylene with various addit./AlMe molar ratios $^{a}$

\begin{tabular}{cccccc}
\hline entry & $\begin{array}{c}\text { addit. (addit. } \\
\text { /AlMe } \\
\text { ratio) }\end{array}$ & $\begin{array}{c}\text { time } \\
(\mathrm{min})\end{array}$ & $\begin{array}{c}\mathrm{m}_{\mathrm{C} 2 \mathrm{H} 4}(\mathrm{~g}) \\
\text { b }\end{array}$ & activity $^{c}$ & $\mathrm{~K}^{\mathrm{d}}$ \\
1 & $\mathbf{1 0}(1 / 5)$ & 60 & 23.2 & 23.2 & 0.66 \\
2 & $\mathbf{1 0}(1 / 2)$ & 25 & 23.3 & 55.9 & 0.69 \\
3 & $\mathbf{1 0}(2 / 3)$ & 12 & 25.1 & 125.5 & 0.70 \\
4 & $\mathbf{1 0}(4 / 5)$ & 60 & 15.7 & 15.7 & 0.67 \\
5 & $\mathbf{1 0}(1 / 1)$ & 60 & $<1$ & $0^{e}$ & - \\
6 & $\mathbf{1 0}(5 / 1)$ & 60 & $<1$ & $0^{e}$ & - \\
$7^{f}$ & $\mathbf{1 0}(2 / 3)$ & 15 & 25.1 & 100.0 & 0.67 \\
$8^{g}$ & $\mathbf{1 0}(2 / 3)$ & 18 & 25.1 & 83.7 & 0.66 \\
$9^{h}$ & $\mathbf{1 0}(2 / 3)$ & 50 & 8.0 & 9.6 & 0.65 \\
$10^{f}$ & $\mathbf{1 1}(2 / 3)$ & 60 & 10.2 & 10.2 & 0.68 \\
$11^{f, i}$ & $\mathbf{1 0}(2 / 3)$ & 60 & 5.1 & 2.6 & n.d. \\
$12^{i}$ & MAO (200 & 120 & 8.8 & 2.2 & n.d. ${ }^{j}$
\end{tabular}

${ }^{a}$ Complex A (10 $\left.\mu \mathrm{mol}\right), \mathrm{AlMe}_{3}$ (500 eq.), toluene (25 mL), $P_{\mathrm{C} 2 \mathrm{H} 4}=30$ bar, $T=50{ }^{\circ} \mathrm{C}$. ${ }^{b}$ mass of ethylene introduced. ${ }^{c}$ $\times 10^{5} \mathrm{~g} \cdot(\mathrm{mol}(\mathrm{Fe}) \cdot \mathrm{h})^{-1} \cdot{ }^{\mathrm{d}} K=$ Schulz-Flory coefficient $=$ $\mathrm{k}_{\text {prop }} /\left(\mathrm{k}_{\text {prop }}+\mathrm{k}_{\mathrm{ch}}\right.$ transfer $)=\operatorname{mol}$ of $\mathrm{C}_{\mathrm{n}+2}$ oligomers $/$ mol of $\mathrm{C}_{\mathrm{n}}$ oligomers. ${ }^{e}$ No ethylene uptake considered $(<1 \mathrm{~g}) .{ }^{f} \mathrm{AlMe}_{3}$ (250 eq.). ${ }^{g} \mathrm{AlMe}_{3}$ (100 eq.). ${ }^{h} \mathrm{AlMe}_{3}$ (50 eq.). ${ }^{i}$ Complex B used as catalyst precursor $(20 \mu \mathrm{mol})$ and $T=80{ }^{\circ} \mathrm{C} .{ }^{J} \mathrm{~K}$ not determined, a short distribution of oligomers was observed (see text). 
${ }^{1} \mathrm{H}$ NMR spectroscopy revealed, after addition of a diol such as 11 to $\mathrm{AlMe}_{3}$ at $-70{ }^{\circ} \mathrm{C}$ in deuterated benzene, broad signals between 0.1 and $-0.3 \mathrm{ppm}$ that may be attributed to organoaluminum oligomers ${ }^{12}$ and sharp singlets at $-0.12,-0.34$ and $-0.79 \mathrm{ppm}$ that were attributed to the trinuclear aluminum complex 16 (Figure 3), by comparison with an authentic sample prepared according to the literature. ${ }^{13}$ Using a similar procedure, the reaction of 2,2'-biphenol with $\mathrm{AlMe}_{3}$ led to a new compound, characterized by ${ }^{1} \mathrm{H}$ and ${ }^{13} \mathrm{C}$ NMR that was tentatively ascribed to the trinuclear species $\mathbf{1 7}$ by analogy with complex 16. No further characterization could however be obtained.

Preliminary tests showed that activated by the welldefined cocatalyst 16, complex A led to oligomerization of ethylene with an activity up to $18.1 \times 10^{5}$ $\mathrm{g} \bullet(\operatorname{mol}(\mathrm{Fe}) \cdot \mathrm{h})^{-1}($ Table 3 , entry 1$)$. Linear alpha olefins were obtained in a full range of $\mathrm{C}_{4}-\mathrm{C}_{24}$ according to a Schulz-Flory distribution $(K=0.68)$. It is noteworthy that cocatalyst $\mathbf{1 6}$ led to a more active catalytic system than the in situ equivalent $\left(18.1 \times 10^{5}\right.$ vs. $10.2 \times 10^{5}$ $\mathrm{g} \bullet(\operatorname{mol}(\mathrm{Fe}) \bullet \mathrm{h})^{-1}$, Tables 3 , entry 1 and Table 2 , entry 10 , respectively). ${ }^{\ddagger}$ Reduction of the cocatalyst to iron ratio from 250 to 10 was reached by increasing the amount of iron complex used for the catalytic tests (to $150 \mu \mathrm{mol}$ ). The activity of this catalytic composition was one order of magnitude lower than when the cocatalyst to iron ratio was $250\left(1.1 \times 10^{5} \mathrm{~g} \bullet(\operatorname{mol}(\mathrm{Fe}) \bullet \mathrm{h})^{-1}\right.$, Table 3 , entry 2$)$. The cocatalyst $\mathbf{1 7}$ proved also to activate catalyst precursor $\mathbf{A}$, with an activity up to $23.2 \times 10^{5} \mathrm{~g} \bullet(\mathrm{mol}(\mathrm{Fe}) \cdot \mathrm{h})^{-1}$, Table 3 , entry 3 ) and a similar selectivity with $K=0.68$. These large multinuclear structures may favor the formation of counterions that form stable ion pairs with cationic iron(II)-alkyl species likely to be considered as the active species in iron-catalyzed oligomerization or polymerization in the presence of MAOs. ${ }^{14}$

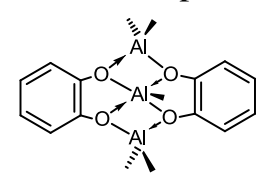

16

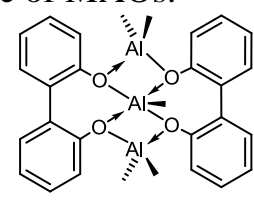

17
Fig 3 Trinuclear aluminum complexes

Table 3. Activation of iron complex $\mathbf{A}$ by well-defined cocatalysts $\mathbf{1 6}$ and $\mathbf{1 7}^{a}$

\begin{tabular}{|c|c|c|c|c|c|}
\hline entr & $\begin{array}{c}\text { cocataly } \\
\text { st }\end{array}$ & $\begin{array}{c}\text { cocatalyst/ } \\
\text { Fe ratio }\end{array}$ & $\underset{(\mathrm{g})^{b}}{\mathrm{~m}_{\mathrm{C} 4}}$ & $\underset{c}{\operatorname{activity}}$ & $\mathrm{K}^{\mathrm{d}}$ \\
\hline 1 & 16 & 250 & 18.1 & 18.1 & 0.68 \\
\hline $2^{e}$ & 16 & 10 & 17.2 & 1.1 & 0.67 \\
\hline 3 & 17 & 250 & 23.2 & 23.2 & 0.68 \\
\hline
\end{tabular}

${ }^{a}$ Complex A $(10 \mu \mathrm{mol})$, toluene $(25 \mathrm{~mL}), \mathrm{P}_{\mathrm{C} 2 \mathrm{H} 4}=30$ bar, $T=$ $50{ }^{\circ} \mathrm{C}, 60$ min. $^{b}$ mass of ethylene introduced. ${ }^{c} \times 10^{5}$ $\mathrm{g} \bullet(\mathrm{mol}(\mathrm{Fe}) \cdot \mathrm{h})^{-1} \cdot{ }^{d} K=$ Schulz-Flory coefficient $=\mathrm{k}_{\text {prop }} /\left(\mathrm{k}_{\text {prop }}+\right.$ $\left.\mathrm{k}_{\mathrm{ch} \text { transfer }}\right)=$ mol of $\mathrm{C}_{\mathrm{n}+2}$ oligomers $/ \mathrm{mol}$ of $\mathrm{C}_{\mathrm{n}}$ oligomers. Complex A $(150 \mu \mathrm{mol})$.

\section{Conclusions}

To conclude, we have established that reactions of phenol-, alcohol- and diol-derivatives with $\mathrm{AlMe}_{3}$ lead to a new generation of cocatalysts, as easy-to-handle materials that promotes the iron complex-catalyzed oligomerization of ethylene. Aromatic diol derivatives are more efficient than phenol or alcohol compounds in the activation process. Among all, the best candidate is the 2,2'-biphenol with an optimum 2,2'-biphenol/AlMe ratio of $2 / 3$. Along with non-isolated mixtures, welldefined isolated cocatalysts were also successfully engaged leading to activation of iron(II) complex showing the potential of our system. Whether the cocatalysts were used in situ or isolated, activities remained lower than with MAO. While the nature of the active species for MAO-activated catalysts remains speculative, the development of such well-defined species, ${ }^{15}$ as promising alternatives, supports further theoretical investigations by DFT to better understand the essential role of the cocatalyst in the activation step. ${ }^{16}$ Further investigations will be focused on the determination of the role of each aluminum atom of the trinuclear structure in the activation process.

\section{Notes and references}

$\$$ It should be noted that $\mathrm{Al} / \mathrm{Fe}$ ratios are different between the two experiments: $\mathrm{Al} / \mathrm{Fe}=750$ for the well-defined cocatalyst 16, $\mathrm{Al} / \mathrm{Fe}=250$ for the cocatalyst formed in-situ. This also suggests that all non-equivalent aluminum atoms do not have the same reactivity.

1 H. S. Zijlstra and S. Harder, Eur. J. Inorg. Chem., 2015, 1, 19; W. Kaminsky, Macromolecules, 2012, 45, 3289; R. Glaser and X. Sun, J. Am. Chem. Soc., 2011, 133, 13323.

2 A. Boudier, P.-A. R. Breuil, L. Magna, H. Olivier-Bourbigou and P. Braunstein, Chem. Commun., 2014, 50, 1398; J. Ma, C. Feng, S. Wang, K.-Q. Zhao, W.-H. Sun, C. Redshaw and G. A. Solan, Inorg. Chem. Front., 2014, 1, 14; L. Li a nd P. D. Gomes, In Olefin Upgrading Catalysis by Nitrogen-based Metal Complexes; Giambastiani, G., Campora, J., Eds.; Springer, 2011.; C. Bianchini, G. Giambastiani, L. Luconi and A. Meli, Coord. Chem. Rev.I, 2010, 254, 431; V. C. Gibson, C. Redshaw and G. A. Solan, Chem. Rev., 2007, 107, 1745.

3 K. P. Bryliakov, E. P. Talsi, N. V. Semikolenova and V. A. Zakharov, Organometallics, 2009, 28, 3225; N. V. Semikolenova, V. A. Zakharov, L. G. Echevskaya, M. A. Matsko, K. P. Bryliakov and E. P. Talsi, Catal. Today, 2009, 144, 334; S. Wang, D. Liu, R. Huang, Y. Zhang and B. J. Mao, J. Mol. Catal. A: Chem., 2006, 245, 122; K.

Radhakrishnan, H. Cramail, A. Deffieux, P. François and A. Momtaz, Macromol. Rapid Commun., 2003, 24, 251; E. P.

Talsi, D. E. Babushkin, N. V. Semikolenova, V. N. Zudin, V. N. Panchenko and V. A. Zakharov, Macromol. Chem. Phys., 2001, 202, 2046.

4 Q. Wang, L. Li and Z. Fan, Eur. Polym. J., 2005, 41, 1170; Q. Wang, L. Li and Z. Fan, J. Polym. Sci. Part A Polym. Chem., 2005, 43, 1599.

5 J. Tudella, M. R. Ribeiro, H. Cramail and A. Deffieux, Macromol. Chem. Phys., 2007, 208, 815; T. Dalet, H. Cramail and A. Deffieux, Macromol. Chem. Phys., 2004, 205, 1394.

6 R. Schmidt, M. B. Welch, S. J. Palackal and H. G. Alt, J. Mol. Catal. A Chem., 2002, 179, 155.

7 M. J. Hanton and K. Tenza, Organometallics, 2008, 27, 5712. 
8 P. Hao, Y. J. Chen, T. P. F. Xiao and W. H. Sun, J. Organomet. Chem., 2010, 695, 90; M. Zhang, P. Hao, W. W. Zuo, S. Y. Jie and W. H. Sun, J. Organomet. Chem., 2008, 693, 483.

9 P.-A. R. Breuil and A. Boudier, US Patent 0211168 A1, 2013.

10 G. Martinez, S. Pedrosa, V. Tabernero, M. E. G. Mosquera and T. Cuenca, Organometallics, 2008, 27, 2300; C.

Krempner, H. Reinke and K. Weichert, Organometallics, 2007, 26, 1386; C.-H. Lin, B. T. Ko, F. C. Wang, C. C. Lin and C. Y. Kuo, J. Organomet. Chem., 1999, 575, 67.

11 A. Boudier, P.-A. R. Breuil, L. Magna, C. Rangheard, J. Ponthus, H. Olivier-Bourbigou and P. Braunstein, Organometallics, 2011, 30, 2640.

12 C. N. McMahon, L. Alemany, R. L. Callender, S. G. Bott and A. R. Barron, Chem. Mater., 1999, 11, 3181.

13 W. Ziemkowska, Main Gr. Met., 2000, 23, 337.

14 M. W. Bouwkamp, E. Lobkovsky and P. J. Chirik, J. Am. Chem. Soc., 2005, 127, 9660; P. M. Castro, P. Lahtinen, K. Axenov, J. Viidanoja, T. Kotiaho, M. Leskelä and T. Repo, Organometallics, 2005, 24, 3664.

15 It should be noted that well-defined trinuclear alkylaluminum tetrachlorocatecholate complexes have been described for $\mathrm{Ni}$ and Pd-based ethylene polymerization: M. Brasse, J. Cámpora, M. Davies, E. Teuma, P. Palma, E. Álvarez, E. Sanz and M. L. Reyes, Adv. Synth. Catal., 2007, 349, 2111.

16 P.-A. R. Breuil, L. Magna and H. Olivier-Bourbigou, Catal. Lett., 2015, 145, 173; Z. Boudene, A. Boudier, P.-A. R. Breuil, H. Olivier-Bourbigou, P. Raybaud, H. Toulhoat and T. de Bruin, J. Catal., 2014, 317, 153.

a. Direction Catalyse et Séparation, IFP Energies nouvelles, Rond point de l'échangeur de Solaize, 69360 Solaize, France.

b. Laboratoire de Chimie de Coordination, Institut de Chimie (UMR 7177 CNRS), Université de Strasbourg, 4 rue Blaise Pascal, F-67081 Strasbourg Cedex, France.

$\dagger$ Electronic Supplementary Information (ESI) available: Syntheses, procedure for catalyst evaluation and ethylene uptakes. See DOI: 10.1039/x0xx00000x 